Creative commons User License: CC BY-NC-ND

Abstracted by: EBSCOhost, Electronic Journals Service (EJS),

Google Scholar, Journal Seek, Scientific Commons,

Food and Agricultural Organization (FAO), CABI and Scopus
Journal of Agricultural Extension

Vol. 22 (1) February, 2018

ISSN(e): 24086851; ISSN(Print); 1119944X

http://journal.aesonnigeria.org

http://www.ajol.info/index.php/jae

Email: editorinchief@aesonnigeria.org

\title{
Factors Affecting Sustainable Animal Trypanosomosis Control in Parts of Kaduna State, Nigeria.
}

https://dx.doi.org/10.4314/jae.v22i1.1

Osue, Hudu Okankhamame*

Research Planning, Monitoring, Extension, Statistics,

Socio-economics Department, Nigerian Institute for Trypanosomiasis Research, P. M. B. 2077, Surame Road, Kaduna, Nigeria. osueho@yahoo.com; +234(0)8076779890;

Lawani, Felix Apeh. Godwin

Formerly Trypanosomiasis Research Department, Nigerian Institute for Trypanosomiasis Research, P. M. B. 2077, Surame Road, Kaduna, Nigeria. Now with the Department of Veterinary Pathology, Faculty of Veterinary Medicine, Federal University of Agriculture, Markudi, Benue State, Nigeria. faglawani@yahoo.com; +234(0)8034085039; $+234(0) 8076777709$

\section{Njoku, Chukwuemeka Ikechukwu}

Nigerian Institute for Trypanosomiasis Research, P. M. B. 2077,

Surame Road, Kaduna, Nigeria. n njokuic@yahoo.com; +234(0)836982869

${ }^{*}$ Corresponding author

\section{Abstract}

This study examined the factors affecting sustainable trypanosomiasis control in parts of Kaduna State within the subhumid savannah ecological zone of Nigeria. Focus group discussions were held with herdsmen and livestock owners $(n=85)$. Questionnaire was administered to participants $(n=25)$ and keyinformants $(n=5)$ were interviewed. Most respondents (80\%) were Fulani by tribe who could read and write Hausa in Arabic text (ajami). Over $70 \%$ were permanent residents practicing transhumant animal husbandry. Animal trypanosomiasis (sammoré), liverfluke (chiwon hanta), worm infestations (helminthosis), and foot and mouth disease (chiwon kafa baki) in Hausa and "boru" in Fulfulde were ranked in decreasing order of important livestock diseases mentioned. A trypanocide (in sachet) identified to be Berenil${ }^{\circledR}$ was administered by livestock farmers themselves. Many livestock owners and some households had lost various numbers of cattle and herds because of animal trypanosomosis. Tsetse flies (kudan tsando) were said to be very common, yet many could not differentiate it from other haematophagous biting flies. During dry season, when forage and water shortage is imminent, there is migration to southern parts of 
Creative commons User License: CC BY-NC-ND

Abstracted by: EBSCOhost, Electronic Journals Service (EJS),

Google Scholar, Journal Seek, Scientific Commons,

Food and Agricultural Organization (FAO), CABI and Scopus
Journal of Agricultural Extension

Vol. 22 (1) February, 2018

ISSN(e): 24086851; ISSN(Print); 1119944X

http://journal.aesonnigeria.org

http://www.ajol.info/index.php/jae

Email: editorinchief@aesonnigeria.org

Nigeria. Annual herd movement to rangelands in nearby Bauchi State was due to perceived increased tsetse fly population in wet season. In addition, about $80 \%$ of arable land was used for crop cultivation. More awareness and preference for pour-on and aerial spraying were higher than the use of traps, target or screens. Rearing of trypanotolerant breeds and zero grazing was never practiced. A private-public partnership in tsetse and animal trypanosomosis control using commercially available trypanocides and insecticide is feasible and should be effectively explored. Any sustainable control strategy envisaged should recognize the level of awareness of the disease and vectors and willingness of grassroots stakeholders to participate and adapt the control methods.

\section{Key Words: Awareness, livestock, indigenous knowledge, socio-economics, trypanosomosis control, tsetse fly.}

\section{Introduction}

The livestock industry in many regions of Africa is left in the hands of a particular tribe. In Nigeria it is dominated by the Fulani who account for over $90 \%$ of herds in the country (Inuwa, 2013). The traditional livestock production system is mainly pastoral or nomadic, and is more pronounced in the arid zone. As humidity increases, agro-pastoral system combining crop and livestock husbandry production is practised. One of the major constraints to optimal land-use for agricultural production is the presence of tsetse flies and animal trypanosomosis (TAT) in vast arable land of sub-Sahara Africa, including Nigeria (Mamoudou et al., 2009a). This has hampered the integration of livestock and crop farming systems (mixed farming). It was felt that a major portion of national herd from the overstocked arid zone will be relocated to the sub-humid zone. The livestock population in the sub-humid zone was estimated to have been reduced by $37 \%$, while the humid zone was by $60 \%$ (Swallow et al., 2000). Previous control projects or programmes did not involve the stakeholders, particularly the rural peasant and nomadic livestock farmers in planning and implementation. Across sub-Saharan Africa, the direct impact on livestock productivity includes reduced meat and milk off take, decreased calving rate, increased both calf mortality rate and the cost of livestock management (Shaw, 2004; Mamoudou et al, 2009b; Chanie et al., 2013). One of the study areas, Lere Local Government Area (LGA) is flanked by the Jos Plateau previously regarded to be tsetse free but now confirmed by Majekodunmi et al, (2013) to have high prevalence of trypanosomiasis infection in cattle, which is influenced by seasonality, altitude and migration practices.

The call for integrated TAT control started gaining ground and three levels of integration were suggested. They include integration with rural development, other disease control measures, or with various tsetse and trypanosomiasis control (Holmes et al., 1997). Whatever approach is used, sustaining the strategy should be paramount. To attain this objective, participation in the control option should be collectively initiated, planned, and 
Creative commons User License: CC BY-NC-ND

Abstracted by: EBSCOhost, Electronic Journals Service (EJS),

Google Scholar, Journal Seek, Scientific Commons,

Food and Agricultural Organization (FAO), CABI and Scopus
Journal of Agricultural Extension

Vol. 22 (1) February, 2018

ISSN(e): 24086851; ISSN(Print); 1119944X

http://journal.aesonnigeria.org

http://www.ajol.info/index.php/jae

Email: editorinchief@aesonnigeria.org

executed by all stakeholders at various levels (Connor and Doran, 1996). Current control relies on the combination of traps, odour baited screens (impregnated with chemical insecticides) and application of pour-on to eliminate the vector (Magona et al., 1998). In addition, the disease is diagnosed and treated using available trypanocides. These methods are regarded to be simple, cheap and environmental friendly. With improved management of livestock, available traditional and modern technologies should be harnessed so that livestock could be raised profitably even in tsetse infested areas with minimal loses in productivity. This will be feasible when the awareness, acceptance, and adoption of research findings are assured. It will largely depend on the social, cultural and economic disposition of livestock farmers and herdsmen towards available control methods. These determinants will influence willingness to adapt modern control techniques, herd management, and input capacity of grassroots operators in tsetse and trypanosomiasis control.

Recently, multidisciplinary approach to disease control has been advocated. The study area is within Kaduna State known to be infested with haematophagus dipteran flies capable of transmitting trypanosomiasis (Ahmed et al., 2005). Also, Abenga et al. (2004) and Enwezor et al. (2009) have established prevalence of animal trypanosomosis in cattle within the ecological zone. The socioeconomic study aspect of these diseases will help to ensure a better management of livestock in tsetse fly infested areas with minimal loses in animal productivity and substantially improve animal health.

\section{Purpose of the Study}

This study assessed the level of awareness among end-users, and identify socioeconomic, cultural and environmental factors that could limit sustainable tsetse and animal trypansomosis (TAT) control. The specific objectives were:

(1) Obtain data on the socioeconomic status and standard of living of the grassroots livestock operators and the existing farming practices etc.

(2) Ascertain the level of indigenous technical knowledge about the vector dynamic and disease prevalence in the study area.

(3) Identify the social and cultural factors that have impacted on input capacity and effective adaptability of available new TAT control technologies to boost livestock production.

\section{Methodology}

\section{Study Area}

The study was carried out in Chikum, Ikara and Lere, LGAs of Kaduna State geospatially situated as shown on the map of Nigeria (Figure 1). A description of the Lere LGA has been presented by Abenga et al. (2004). Briefly, Lere LGA is a plain lowland area at the fringe of Jos Plateau. The study areas lie within the sub-humid ecological zone of Nigeria along guinea savannah vegetation belt. With a rainfall of over $1600 \mathrm{~mm}$ and wet season that last between May and October. The inhabitants are mostly farmers who grow mainly 
Creative commons User License: CC BY-NC-ND

Abstracted by: EBSCOhost, Electronic Journals Service (EJS),

Google Scholar, Journal Seek, Scientific Commons,

Food and Agricultural Organization (FAO), CABI and Scopus
Journal of Agricultural Extension

Vol. 22 (1) February, 2018

ISSN(e): 24086851; ISSN(Print); $1119944 X$

http://journal.aesonnigeria.org

http://www.ajol.info/index.php/jae

Email: editorinchief@aesonnigeria.org

grains (maize, millet, and rice). In addition, these areas are well known to accommodate a good number of cattle herds. The herdsmen and livestock owners $(n=85)$ who participated in focus group discussions varied from 8-12 persons were mostly Fulani. Respondents were all males between 18 to 70 years of age, with 10 years or more residencies. The key-informants interviewed were the district and village heads, Sarki Fulani, and the chairman, Miyyetti Allah Cattle Breeders Association of Nigeria (MACBAN), Lere LGA Branch.

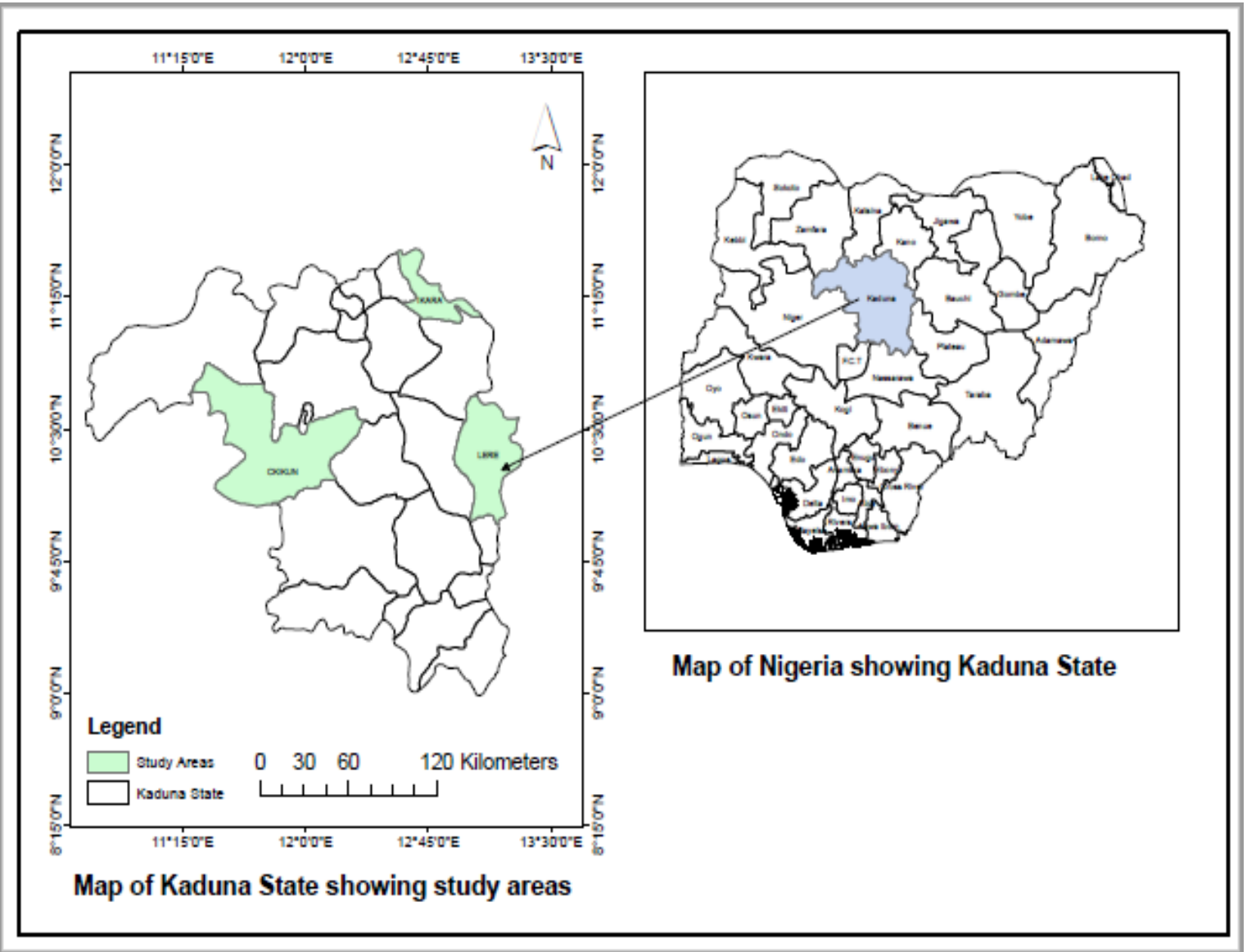

Figure 1: Map of Nigeria showing Kaduna State and enlarged insert of the study areas of Chikun, Ikara and Lere Local Government Areas.

The main trusts of the questions were to assess the awareness, indigenous and acquired knowledge about the disease, its vector, and control methods, and the signs used to diagnose the disease. Respondents were asked how they got veterinary services or treated their sick animals, and probe if local method of medication was practiced? We requested for local names, samples, and mode of application of drugs used. We assessed the perception about the important flies in the area, description of tsetse fly, where and when they are found. Their ability to differentiate tsetse from other biting flies from among samples provided. A thematic diagnostic survey of the study areas was 
Creative commons User License: CC BY-NC-ND

Abstracted by: EBSCOhost, Electronic Journals Service (EJS),

Google Scholar, Journal Seek, Scientific Commons,

Food and Agricultural Organization (FAO), CABI and Scopus
Journal of Agricultural Extension

Vol. 22 (1) February, 2018

ISSN(e): 24086851; ISSN(Print); 1119944X

http://journal.aesonnigeria.org

http://www.ajol.info/index.php/jae

Email: editorinchief@aesonnigeria.org

undertaken. Twenty-five herdsmen/livestock owners were administered questionnaire. An interpreter was used to facilitate effective communication.

\section{Results and Discussion}

\section{Respondents' Socioeconomic Profile}

The mean age and standard deviation of respondents was $48.64 \pm 13.18$ with a range between 20-70 years. They were all Muslims and $96 \%$ were Fulani by tribe. All were illiterate by Western educational standard and $3(12 \%)$ can read while $7(28 \%)$ can read and write Hausa and Arabic. Majority owns a transistor radio and a bicycle, and lives in thatched houses in farming/grazing locations. Each herdsman holds an average of 59.64 \pm 51.54 head of cattle (with a range 11-150), 16.45 \pm 9.22 (5-30) sheep and $19.94 \pm 18.95$ (1-80) goats. The mean annual calf rate was $12.04 \pm 9.24(2-40), 6.07 \pm 3.79$ $(2-15)$ and $7.69 \pm 7.60(0-30)$ for cattle sheep and goat respectively. Animal husbandry practice was $80 \%$ nomadic, $16 \%$ homestead and $4 \%$ house hold rearing. Radio is owned by 22 (88\%). While majority of them $21(88 \%)$ own thatched houses as against $3(12 \%)$ with zinc houses. Only one (4\%) own a vehicle, 3(12\%) own a motorcycle and $17(68 \%)$ own a bicycle. Mixed agriculture and pastoral (agro/livestock) farming is practiced by most of those interviewed $17(68 \%)$. Additional benefit is derived from subsistence farming largely in guinea corn and maize. They also cultivate millet, rice, pepper and onions in decreasing order of output. Other benefits accruing from livestock are manure used for farming and milk for both house hold consumption and sales.

The respondents lack access to public utilities like pipe borne water, electricity as they live in remote farming/grazing locations about $5-10 \mathrm{~km}$ away from the nearest village or community. Complaint by herdsmen to have lost various numbers of cattle was corroborated by Key-informant statements. A good number of households lost their herds to the disease. Sammoré and helminthosis influenced culling of cattle, while rinderpest was said to be a major factor many years ago. Important interaction between crop farmers and livestock farmers was by exchanging manure in return for crop by-products. The observed low level awareness of tsetse fly and animal trypanosomosis control will no doubt impede implementation of any control strategy to be introduced as observed in past studies by Chanie et al, (2013). Although a good number of respondents was aware of animal trypanosomiasis but unable to diagnose the disease. There were ignorant of the cause and spread of the disease. These will invariably hinder grassroots participation in TAT control in particular and veterinary diseases in general. Therefore, there is greater need for enlightenment campaign before the use of traps, insecticide, chemotherapy and trypanotolerant animal breeding TAT control strategies can be introduced and adapted by the grassroots stakeholders. Majority of the respondents carried out mixed livestock and crop farming. Income is derived mainly from sale of animals, cow milk off-take for household consumption, and sales in local market. Added benefit is derived from subsistence farming largely in maize, guinea corn, millet, and rice. Only few $20 \%$ herdowners used animals for traction and most peasant crop farmers relied on manual labour for land cultivation. 
Creative commons User License: CC BY-NC-ND

Abstracted by: EBSCOhost, Electronic Journals Service (EJS),

Google Scholar, Journal Seek, Scientific Commons,

Food and Agricultural Organization (FAO), CABI and Scopus
Journal of Agricultural Extension

Vol. 22 (1) February, 2018

ISSN(e): 24086851; ISSN(Print); 1119944X

http://journal.aesonnigeria.org

http://www.ajol.info/index.php/jae

Email: editorinchief@aesonnigeria.org

\section{Awareness of the Vector, Disease and the Control Methods}

Most respondents were of the view that biting flies were a major problem in the area. Tsetse fly (kudan tsando) was said to be common especially during the rainy season, when there was population build-up and dispersal; but during dry season, tsetse fly population was restricted within forest galleries. Increase contact between animal and tsetse fly is said to occur more at watering locations during dry season. Of all the veterinary health problems, animal trypanosomiasis (sammoré) was the most frequently mentioned, followed by liver fluke (chiwon hanta) and foot and mouth disease (chiwon kafa baki) or "boru" in Fulfude. According to Mbahin et al. (2006), animal trypanosomosis remains as the most important and most common lethal cattle disease. About $68 \%$ of those interviewed affirmed knowing the disease had existed in $13(52 \%)$ of the herds at one time or the other. Often other diseases $(40 \%)$ followed by worms (helminthiasis) $(28 \%)$, sammoré $(16 \%)$ and rinderpest $(16 \%)$ had affected the animals. All the respondents (100\%) could tell few clinical signs and symptoms of the disease. Among the clinical signs and symptoms used in diagnosing animal trypanosomiasis included emaciation, poor hair coat, lacrimation, and geophagia. Most herdsmen stated that at postmortem of infected animals, the meat looks watery, yellowish, with excessive discharges, and oedematous. Physical screening of herds showed that many cattle were emaciated to varying degree and preformoral lymph nodule swelling was predominant is in agreement with the observation made by Grace et al. (2009). The respondents' awareness of the disease was $44 \%$, of the vector tsetse fly $36 \%$ and the Nigerian Institute for Trypanosomiasis Research (NITR) was 36\%. Among those who claimed to have heard of tsetse said it is found in streams and rivers but most respondent do not know the function of NITR. A study in Ugandan by Bardosh (2015) held that a fundamental tension between business incentive and vector control, showed how divergence in knowledge, power, values, and social norms shaped project implementation and community responses. Most herds (90\%) were Zebu breed of Taurin sparse with red buroro and no evidence of Ndama breed being kept.

\section{Use of Indigenous Control Methods}

Apart from burning cow dung and making campfire to repel biting flies at night, they move animals out for grazing at the latter part of morning and return before dark. Applications of indigenous technical knowledge for TAT control and the respondents' perception about their effectiveness are highlighted on Table 1. Among the few (20\%) who affirmed to have used traditional treatment methods in the past, also claimed to have abandoned the practice for its ineffectiveness. Herbs used included "Árárrábíi" Commiphora kerstingii; Boswellia dalzielii; B. odorata (tree bark) and bitter garden-eggs or "Gáután dáácíi", Solanum incanum alone or combined with "Dùkkí pl. dúkkóókíi" commonly called nettle tree or Celtis integrifolia was used for treating sammoré. Herdsmen apply "Gàrààfúníi" or Momordica balsamina; M. charantia,"Mádààcíi pl. Mààdààtái" or Khaya senegalensis and potash for treatment of other diseases. Both water and methanol extracts of $C$. integrifolia were among samples of forty selected medicinal plants found to have 
Creative commons User License: CC BY-NC-ND

Abstracted by: EBSCOhost, Electronic Journals Service (EJS),

Google Scholar, Journal Seek, Scientific Commons,

Food and Agricultural Organization (FAO), CABI and Scopus
Journal of Agricultural Extension

Vol. 22 (1) February, 2018

ISSN(e): 24086851; ISSN(Print); $1119944 X$

http://journal.aesonnigeria.org

http://www.ajol.info/index.php/jae

Email: editorinchief@aesonnigeria.org

potential anti-trypanosome activities by Bizimana et al. (2006). The finding from this study is similar to that of Usman et al. $(2015 ; 2017)$ that concluded that indigenous control methods were well established and utilized by the respondents. Obtaining information on ethno-veterinary practice is somehow difficult (Nalule et al., 2011). Livestock farmers concerned take this aspect as probing into family guided secret thereby exhibiting unwillingness to disclose how they treat animals. The Hausa names of plants mentioned and the scientific names were identified using the Blench, (2007) compilations.

Table 1: Highlights of existing indigenous technologies for tsetse and animal trypanosomosis control

\begin{tabular}{|c|c|c|c|}
\hline Technology & Practices & $\begin{array}{l}\text { Assumption or desired } \\
\text { effectiveness }\end{array}$ & Remarks \\
\hline Grazing time & $\begin{array}{l}\text { Herd leaves late mornings and } \\
\text { return at sunset }\end{array}$ & Minimize host-fly contact & $\begin{array}{l}\text { A common practice by } \\
\text { all } 100 \% \text {. }\end{array}$ \\
\hline $\begin{array}{l}\text { Burning of cow } \\
\text { dung. }\end{array}$ & To generate smoke. & It repels biting flies & $\begin{array}{l}\text { Practiced by majority } \\
(70 \%) \text {. }\end{array}$ \\
\hline $\begin{array}{l}\text { Making of camp } \\
\text { fire }\end{array}$ & To produce smoke and heat. & $\begin{array}{l}\text { It repels both biting flies and } \\
\text { predators at night. }\end{array}$ & $\begin{array}{l}\text { Practiced by majority } \\
(70 \%) \text {. }\end{array}$ \\
\hline $\begin{array}{l}\text { 'Traditional' } \\
\text { diagnosis }\end{array}$ & $\begin{array}{l}\text { Clinical signs and symptoms } \\
\text { were used. }\end{array}$ & $\begin{array}{l}\text { Emaciation, poor hair coat, loss } \\
\text { of appetite, geophagia, etc. }\end{array}$ & Practiced by all $100 \%$. \\
\hline $\begin{array}{l}\text { Traditional } \\
\text { treatment }\end{array}$ & $\begin{array}{l}\text { Cattle were fed on tree barks } \\
\text { grinded with potash. }\end{array}$ & $\begin{array}{l}\text { Treatment based on clinical signs } \\
\text { and symptoms. }\end{array}$ & $\begin{array}{l}\text { Only } 20 \% \text { admitted } \\
\text { using local method. }\end{array}$ \\
\hline
\end{tabular}

\section{Adaptability of New Tsetse and Trypanosomiasis Control Methods}

Many respondents $(80 \%)$ do not patronize the veterinary clinic, and few that do, were apprehensive of personnel that present themselves as veterinarian. Many herdsmen $(60 \%)$ disclosed using trypanocide in sachet found to be Berenil ${ }^{\circledR}$ purchased from open market and administered by them. This drug has been reported to be widely used by Seyoum et al, (2013) and Anthony and Maikai, (2017). Table 2 shows the analysis of viability or needs, acceptability or belief and validity or perception ratings according to Rous 1993 of TAT control technologies. Interestingly, the use of pour-on was embraced by all $(100 \%)$ and appeared more attractive than tsetse traps and screens that were not well known to them. Although bereft of modern technical knowhow, the respondents were fully aware about the vector and disease as observed by Njoku et al, (2003). Their needs and beliefs affect what knowledge is gained, what facts are sought, and how both are interpreted. In order to raise the level of awareness about modern TAT control methods, extension visits is critical to attaining sustainable agricultural development (Aaron, 2011). The options available will rely on radio as a veritable tool to reach out to end users, particularly the Fulani pastoralists. Enlightenment programs in Fulfulde and Hausa directed at the main target group, as majority carry transistor radio wherever they go even when grazing animals in the field. Pamphlet and poster illustrations in Hausa 
Creative commons User License: CC BY-NC-ND

Abstracted by: EBSCOhost, Electronic Journals Service (EJS),

Google Scholar, Journal Seek, Scientific Commons,

Food and Agricultural Organization (FAO), CABI and Scopus
Journal of Agricultural Extension

Vol. 22 (1) February, 2018

ISSN(e): 24086851; ISSN(Print); $1119944 X$

http://journal.aesonnigeria.org

http://www.ajol.info/index.php/iae

Email: editorinchief@aesonnigeria.org

written in Arabic text (ajami) can be comprehended by majority of them. It is well documented that most livestock population are in the hands of Fulani nomadic pastoralists (Inuwa, 2013). Whether the indigenous control methods of burning cow dung and making campfire at night could reduce mechanical transmission of Trypanosoma vivax remained to be verified. Strategic management of herd grazing time cannot eliminate the risk of trypanosomiasis transmission occurring, irrespective of the harshness of the dry season climate (Rawlings et al., 1994). Nevertheless, the livestock farmers hold tenaciously to the belief that the indigenous or orthodox methods might provide some degree of control by curtailing host-fly contact. This assertion is not backed by empirical data from research to compare their efficacies with the new modern control methods. Awareness of trypanotolerant breeds and other control options are shown on Table 2.

Commercial availability of both trypanocides and insecticides earlier introduced to them at subsidized rates has clearly demonstrated the feasibility of public-private sector initiative in TAT control as suggested by Swallow et al. (1995). Secondly, application of pour-on will not only control mechanical transmission of trypanosomes by Tabanids and Stomoxys (Baylis and Stevenson, 1998; Gumel et al., 2015), it will equally protect against tick infestations (Bauer et al, 2001). Therefore, moving target vector control using pouron was more accepted (as private good) than the stationary target control using trap, target and screen. Treatment of livestock with trypanocides (viewed as public good) by Cattand et al., (2010) is more suited to transhumance practice than others. This corroborated Bastiaensen et al, (2004) observation that factors such as the importance of animal traction, existing relationships between stockholders, and the respondents' knowledge of disease, and insecticide available, importance farmers attach to tick control and health status of animals in northern Togo determined the acceptance of control methods. 
Table 2: Summary of the viability, acceptability and validity of tsetse and animal trypanosomosis control technologies.

\begin{tabular}{|c|c|c|c|c|}
\hline $\begin{array}{c}\text { Control } \\
\text { Technology }\end{array}$ & $\begin{array}{l}\text { Viability } \\
\text { (Need) }\end{array}$ & $\begin{array}{c}\text { Acceptability } \\
\text { (Belief) }\end{array}$ & $\begin{array}{c}\text { Validity } \\
\text { (Perception) }\end{array}$ & $\begin{array}{c}\text { Views } \\
\text { (Remarks) }\end{array}$ \\
\hline $\begin{array}{l}\text { Trap, target } \\
\text { and screen }\end{array}$ & $\begin{array}{l}\text { Relatively new } \\
\text { to all the } \\
\text { respondents. }\end{array}$ & $\begin{array}{l}\text { It has not been } \\
\text { used, so cannot } \\
\text { be appreciated. }\end{array}$ & $\begin{array}{l}\text { There is need to } \\
\text { raise their } \\
\text { awareness. }\end{array}$ & $\begin{array}{l}\text { Not suited to } \\
\text { transhumant } \\
\text { practice. }\end{array}$ \\
\hline $\begin{array}{l}\text { Insecticide } \\
\text { spray on } \\
\text { cattle }\end{array}$ & $\begin{array}{l}\text { Available, } \\
\text { affordable, and } \\
\text { easy to apply. }\end{array}$ & $\begin{array}{l}\text { It protected cattle } \\
\text { from tsetse flies } \\
\text { and ticks. }\end{array}$ & $\begin{array}{l}\text { High } \\
\text { performance, } \\
\text { and appealing }\end{array}$ & $\begin{array}{l}\text { It was } \\
\text { introduced by } \\
\text { PTF* and is }^{*} \text { sustainable. }\end{array}$ \\
\hline $\begin{array}{l}\text { Aerial and } \\
\text { ground } \\
\text { spraying. }\end{array}$ & $\begin{array}{l}\text { Rated the best } \\
\text { and most } \\
\text { effective control } \\
\text { by older } \\
\text { respondents. }\end{array}$ & $\begin{array}{l}\text { Clamour for it } \\
\text { despite its } \\
\text { negative impact } \\
\text { on environment. }\end{array}$ & $\begin{array}{l}\text { Many attributed } \\
\text { disease } \\
\text { resurgence to } \\
\text { long interval of } \\
\text { spray. }\end{array}$ & $\begin{array}{l}\text { Huge cost to } \\
\text { cover vast } \\
\text { areas infested } \\
\text { with tsetse } \\
\text { flies. }\end{array}$ \\
\hline $\begin{array}{l}\text { Breeding } \\
\text { trypano- } \\
\text { tolerant } \\
\text { animals }\end{array}$ & $\begin{array}{l}\text { Most } \\
\text { respondents } \\
\text { were not used } \\
\text { to the breeds. }\end{array}$ & $\begin{array}{l}\text { Its small size and } \\
\text { assumed low } \\
\text { productivity had } \\
\text { made it } \\
\text { unattractive to } \\
\text { them. }\end{array}$ & $\begin{array}{l}\text { Breeds not } \\
\text { suited to the } \\
\text { extensive } \\
\text { grazing system. }\end{array}$ & $\begin{array}{l}\text { Extension and } \\
\text { OFAR* }^{*} \text { are } \\
\text { required. }\end{array}$ \\
\hline $\begin{array}{l}\text { The use of } \\
\text { trypanocidal } \\
\text { drugs }\end{array}$ & $\begin{array}{l}\text { Drugs are } \\
\text { available in the } \\
\text { open market. }\end{array}$ & $\begin{array}{l}\text { Drugs were } \\
\text { purchased by } \\
\text { herdsmen and } \\
\text { administered by } \\
\text { them. }\end{array}$ & $\begin{array}{l}\text { The drugs were } \\
\text { used without } \\
\text { any veterinary } \\
\text { supervision. }\end{array}$ & $\begin{array}{l}\text { Drug resistant } \\
\text { strains may } \\
\text { develop and } \\
\text { spread. }\end{array}$ \\
\hline $\begin{array}{l}\text { Zero grazing } \\
\text { and ranching } \\
\text { system }\end{array}$ & $\begin{array}{l}\text { A shift from } \\
\text { nomadic } \\
\text { practice to } \\
\text { transhumant } \\
\text { system. }\end{array}$ & $\begin{array}{l}\text { Most respondents } \\
\text { depend on } \\
\text { extensive grazing } \\
\text { system. }\end{array}$ & $\begin{array}{l}\text { Livestock feeds } \\
\text { are both not } \\
\text { available and } \\
\text { not cost } \\
\text { effective. }\end{array}$ & $\begin{array}{l}\text { Used by those } \\
\text { that fattens or } \\
\text { holds few } \\
\text { livestock. }\end{array}$ \\
\hline
\end{tabular}

${ }^{*}$ On-farm adaptive research (OFAR) and Petroleum Trust Fund (PTF).

\section{Cultural and Institutional Factors that Could Influence Sustainable TAT Control}

Traditional Fulani leadership system and the pan Fulani sociocultural group, the Miyyetti Allah Cattle Breeders Association Nigeria exists. The offices of State Agricultural Development Project (ADP) and Veterinary clinic were situated at the LGA headquarters. 
Creative commons User License: CC BY-NC-ND

Abstracted by: EBSCOhost, Electronic Journals Service (EJS),

Google Scholar, Journal Seek, Scientific Commons,

Food and Agricultural Organization (FAO), CABI and Scopus
Journal of Agricultural Extension

Vol. 22 (1) February, 2018

ISSN(e): 24086851; ISSN(Print); 1119944X

http://journal.aesonnigeria.org

http://www.ajol.info/index.php/jae

Email: editorinchief@aesonnigeria.org

Only one nomadic primary school with a two-classroom mud building and a tent was seen in Saminaka, Lere LGA. However, cooperation and coordination among relevant institutions and organizations were lacking. Also the strong influence of the existing hierarchy of traditional leadership Ardo, Sarki Fulani, Village Head, District Head and the Emir should be enlisted if optimal compliance of stockholders is to be achieved. In the field, it is very difficult to deal directly with a Fulani herdsman/livestock owner individually. Failure of top-down approach to agricultural and rural development projects especially in developing countries like Nigeria was identified in this study. This was typified by poor patronage of veterinary clinic and the inability of state ADP and LGA Agriculture Dept to manage TAT control. In addition, the apprehension about private veterinarian would affect sustainability of TAT control. Konde, (1998) have stressed importance of farmers not only participating but taking a leading role in planning and implementing agricultural and rural development projects. Interestingly, this survey was a response to calls by the LGA and the MACBA. As major portion of available arable land in the study area was used for cultivating crop, support the statement that both land-use planning and tsetse control generally lacked coordination within development programs (Swallow, 2000). This has made the area to be highly prone to conflict between farmers and pastoralists. In addition, it will make it difficult to realize the optimal mixed crop and livestock farming potential of the area.

\section{Environmental Factors}

Over $60 \%$ of the area was utilized for farming activities during the year leaving pockets of marginal wooded forestland for grazing activities. The rivers and rivulets are mostly perennial while rainfall last between May and October, with a peak in August. Many farmers $(80 \%)$ believed tsetse fly activities were higher during wet season especially the period when maize flowers. Only in Lere LGA, it was observed that most herdsmen $(70 \%)$ move their herds to rangelands elsewhere, preferably in Bauchi State. This temporary movement of cattle northward during wet season was attributed to increasing tsetse fly menaces; the Key-Informants opined it was to avoid conflict between crop farmers and livestock owners. Apparently, most arable land with good pasture would be under cultivation leaving the few herds that remains were confined to graze within marginal lands particularly along the river forest galleries.

Past aerial spraying had greatly disturbed the natural fauna with few monkeys, reptiles, and antelopes been the only game animals that can be found in the area. The biting flies were Stomoxys calcitrans, Tabanidae (horse fly), and Haematobia (Syphona) irritans (horn fly) found swarming around animals. Migration to southern parts of the country occurs mainly during the dry season when food and water shortages were imminent. Many respondents (65\%) particularly those aged 40 years and above remembered that tsetse fly control was last undertaken in the area in the early 1980's by means of aerial spraying. The older respondents and key-informants (100\%) wanted a repeat of the spraying exercise despite it resulted in death of fishes in rivers and game animals. 
Creative commons User License: CC BY-NC-ND

Abstracted by: EBSCOhost, Electronic Journals Service (EJS),

Google Scholar, Journal Seek, Scientific Commons,

Food and Agricultural Organization (FAO), CABI and Scopus
Journal of Agricultural Extension

Vol. 22 (1) February, 2018

ISSN(e): 24086851; ISSN(Print); 1119944X

http://journal.aesonnigeria.org

http://www.ajol.info/index.php/jae

Email: editorinchief@aesonnigeria.org

Resurgence of vector and disease was blamed on Government neglect to control the disease by aerial spraying.

\section{Conclusion and Recommendations}

For a sustainable TAT control to be attained, it requires proper use of veterinary drugs and insecticides. A change in the existing land-use policy for agricultural purposes has to recognize the benefits from interaction between crop and livestock farming systems in land allocation. This will checkmate cultivation of most arable land and forestall clashes between crop farmers and pastoralists. It will also prevent or minimize wet season migration. Enlightenment campaign programme and technology transfer to the Fulani pastoralist in particular and livestock farmers in general should be articulated using extension services and OFAR, respectively. More importantly, effective linkages among institutions and organizations involved in livestock production and disease control is not only imperative but also desirable. A panacea for participatory TAT control should include the promotion of private public partnership. Activities of all stakeholders involved in agroveterinary manufacturing and marketing of insecticides and trypanocides, government institutions in charge of livestock disease research and control, and the various categories of stockholders must be well-coordinated.

\section{Acknowledgements}

Many thanks go to the Management of the Nigerian Institute for Trypanosomiasis Research for funding this project. The cooperation of the Chairmen, Heads of Agriculture Department, Traditional Rulers and officials of Miyatti Allah Cattle Breeders Association of Nigeria of Chikun, Ikara and Lere Local Government Areas of Kaduna State are highly appreciated. We are grateful to the livestock owners and herdsmen that voluntarily participated in the study.

\section{References}

Aaron, R. (2011). Indigenous Knowledge and its Role to Sustainable Agriculture in Ekiti State, Nigeria. International Journal of Science and Rural Development. 6(24): 34-39.

Abenga, J. N., Enwezor, F. N. C., Lawani, F. A. G., Osue, H. O. and Ikemere, E. C. D. (2004). Trypanosome prevalence in cattle in Lere Districts of Kaduna State, Northern Nigeria. Revue d'elevage et de medicine veterinaire des pays topicalaux 57(1-2):45-48.

Ahmed, A. B., Okiwelu, S. N. and Samdi, S. M. (2005). Species diversity, abundance and seasonal occurrence of some biting flies in Southern Kaduna, Nigeria. African Journal of Biomedical Research, 8: 113-118.

Anthony, J. and Maikai, V. A. (2017). Survey on knowledge of trypanosomosis amongst livestock farmers in Kachia and Saminaka local government areas of Kaduna state, Nigeria. Sokoto Journal of Veterinary Sciences, 15(1): 42-48. 
Creative commons User License: CC BY-NC-ND

Abstracted by: EBSCOhost, Electronic Journals Service (EJS),

Google Scholar, Journal Seek, Scientific Commons,

Food and Agricultural Organization (FAO), CABI and Scopus
Journal of Agricultural Extension

Vol. 22 (1) February, 2018

ISSN(e): 24086851; ISSN(Print); 1119944X

http://journal.aesonnigeria.org

http://www.ajol.info/index.php/jae

Email: editorinchief@aesonnigeria.org

Bardosh, K. L. (2015). Deadly flies, poor profits, and veterinary pharmaceuticals: sustaining the control of sleeping sickness in Ugadan. Medical Anthropology, 10: 1-15.

Bastiaensen, P., Kouagou, N. T., Gnofam, M., Batawii, K., Napla, A. and Hendrickx, G. (2004). Acquisition of a new tsetse fly control technique by farmers of the north togo: socioeconomic aspects. Bulletin of animal Health and Production in Africa, 52 (3): 142-158.

Bauer, B., Kaborë, I., Liebisch, A., Meyer, F. and Petrich-Bauer, J (2001). Simultaneous control of ticks and tsetse flies in Satiri, Burkina Faso, by the use of fumethrin pour-on for cattle. Tropical Medicine and Parasitology, 43: 41-46.

Baylis, M. and Stevenson, P. (1998). Trypanosomiasis and tsetse control with insecticidal pourons-facts or fiction. Parasitol. Today. 14(2): 77-82.

Bizimana , N., Tietjen , U., Zessin ,K., Diallo, D., Djibril, C., Melzig, M. F., Clausen, P-H. (2006). Journal of Ethnopharmacology 103 (2006) 350-356

Blench, R. (2007). Hausa names of plants. Hausa Plant-names-Hausa-Latin $2^{\text {nd }}$ Edition. Ciculation version. Inprint Downloaded December, 2007. Pp1-67.

Cattand, P., Simmaro, P., Jannin, J., Ly, C., Fall, A., Shaw, A. and Mattioli, R. (2010). Linking sustainable human and animal African trypanosomiasis control with rural development strategies. PAAT Information Service Publication, World Health Organization, Geneva and Food and Agricultural Organization, Rome. PAAT Technical and Scienfic Series 10. pp64.

Chanie, M., Adula, D. and Bogale, B (2013). Socio-Economic Assessment of the Impacts of Trypanosomiasis on Cattle in Girja District, Southern Oromia Region, Southern Ethiopia. Acta Parasitologica Globalis, 4 (3): 80-85, DOI: 10.5829/idosi.apg.2013.4.3.7523

Connor, R. J. and Doran, M. (1996). The critical role of data collection and information management in policy-making and implementation. Regional Tsetse and Trypanosomiasis Control Programmes, Harare, Zimbabwe.

Enwezor, F. N. C., Umoh, J. U., Zaria, L. T. and Anere, J. I. (2009). Survey of bovine trypanosomosis in the Kachia grazing reserve, Kaduna state, Nigeria. Veterinary Parasitology, 159(2): 121-125.

Grace, D., Randolph, T., Affognon, H., Dramane, D., Diall, O. and Clausen, P. H. (2009). Characterization and validation of farmers' knowledge and practice of cattle trypanosomosis management in the cotton zone of West Africa. Acta Tropica, 111(2): 137-143.

Gumel, M. A., Manu, A.Y. and Qadeer. M. A. (2015). Evaluation of cattle rearer's knowledge, attitude and practices about tsetse fly in Muri district, Taraba State, Nigeria. Bayero Journal of Pure and Applied Sciences, 6(1): 127 - 131. 
Creative commons User License: CC BY-NC-ND

Abstracted by: EBSCOhost, Electronic Journals Service (EJS),

Google Scholar, Journal Seek, Scientific Commons,

Food and Agricultural Organization (FAO), CABI and Scopus
Journal of Agricultural Extension

Vol. 22 (1) February, 2018

ISSN(e): 24086851; ISSN(Print); 1119944X

http://journal.aesonnigeria.org

http://www.ajol.info/index.php/jae

Email: editorinchief@aesonnigeria.org

Holmes, P. H. (1997). New approaches to the integrated control of trypanosomiasis. Vet. Parasit. 71 (2-3): 121-135.

Inuwa, M. (2013). Nigerian Livestock Resources, the Need to Harness. A Review. Journal of Agro-science. 3(2): 98-111

Konde, A. (1998). Farmers' participation in agricultural research: experiences from Ethiopia. In Food, lands and livelihoods-setting research agendas for animal science. Br. Soc. Anim. Sc. (Eds) Gill, M., Owen, E. and Lawrence, T.L.J. Occasional Publication No. 21: 101-109.

Magona, J. W., Okuna, N. M., Katabazi, B. K., Omollo, P., Okoth, J. O., Mayende, J. S. P. and Drabile, D. C. (1998). Control of tsetse and animal trypanosomosis using a combination of tsetse trapping, pour-on and chemotherapy along the Uganda-Kenya border. Revue d' El. et de Med. veterinaire des Pays tropicaux. 51 (4): 311-315.

Majekodunmi, A. O., Fajinmi, A., Dongkum, C., Picozzi, K., Thrusfield, M. V. and Welburn, S. G. (2013). A longitudinal survey of African animal trypanosomiasis in domestic cattle on the Jos Plateau, Nigeria: prevalence, distribution and risk factors. Parasites \& Vectors20136:239.DOI: 10.1186/1756-3305-6-239

Mamoudou, A., Zoli, A., Tchoua, P. 2009a. Parasitological prevalence of bovine trypanosomosis in the Faro and Deo division valley of the Adamaoua plateau, Cameroon. International Journal of Biological and Chemical Sciences. 3(5): 1192-1197.

Mamoudou, A; Zoli, A; Van Den Bossche, P; Delespaux, V; Cuisance, D. and Geerts, S. (2009). Half a century of tsetse and animal trypanosomosis control on the Adamawa plateau in Cameroon. Revue Elev. Med. Vet. Pays trop. 62(1): 1-6.

Mbahin, N., Zoli, A., Mamoudou, A., Tanenbe, C., Abah, S., Ghogomu, RT, Nouala, SF, Njeumi, F. (2006). Livestock owners' perception on trypanosomosis and associated treatment on the Adamaoua plateau in Cameroon ten years after tsetse eradication. Bull. Anim. Hlth. Prod. Afr. 54: 260-270.

Nalule, A. S; Mbaria, J. M.; Olila, D. and Kimenju, J. W. (2011). Ethno-pharmacological Practices in Management of Livestock Helminthes by Pastoral Communities in the Drylands of Uganda. Livestock Research for Rural Development, 23 (2):1-27.

Njoku, C. I., Uzoigue, N. R., Afaghoma, V. N., Abubakar, A. and Usman, B. (2003). Community Perception of Animal Trypanosomosis in Durbi village, Jos East Local Government Area of Plateau State, Central Nigeria. In: Proceedings of the 27th Meeting of the ISCTRC, * Pretoria, South Africa. Pp. 199 - 204.

Programme Against African Trypanosomiasis (1998). Drug management and parasite resistance in bovine trypanosomiasis in Africa. PAAT Tech. and Scient. Series 1. 1-31.

Rawlings, P., Wacher, T. J. and Snow, W. F. (1994). Cattle-tsetse contact in relation to the daily activity patterns of Glossina morsitans submorsitans in the Gambia. Med. and Vet. Entomol. 8(1): 57-62. 
Creative commons User License: CC BY-NC-ND

Abstracted by: EBSCOhost, Electronic Journals Service (EJS),

Google Scholar, Journal Seek, Scientific Commons,

Food and Agricultural Organization (FAO), CABI and Scopus
Journal of Agricultural Extension

Vol. 22 (1) February, 2018

ISSN(e): 24086851; ISSN(Print); $1119944 X$

http://journal.aesonnigeria.org

http://www.ajol.info/index.php/jae

Email: editorinchief@aesonnigeria.org

Rouse, W.B. (Ed) (1993). Concepts and principles for enabling innovation. In. Catalysts for change. Wiley-Interscience Pub. Pp 249.

Seyoum Z., Terefe, G. and Ashenafi, H. (2013). Farmers' perception of impacts of bovine trypanosomosis and tsetse fly in selected districts in Baro-Akobo and Gojeb river basins, Southwestern Ethiopia. BMC Veterinary Research, 9: 214.

Shaw, A. (2004). The economics of African trypanosomiasis. In I. Maudlin, P. holmesw and M. Miles, eds. The trypanosomiasis, pp369-402. Wallingford, UK, CABI Publishing.

Swallow, B. M., Woudyalew, M. and Leak, S. G. A. (1995). Potential demand for mixed publicprivate animal health input: evaluation of a pour-on insecticide for controlling tsetsetransmitted trypanosomiasis in Ethiopia. Prev. Vet. Med. 24: 265-275.

Swallow, B.M. (2000). Impact of trypanosomosis on African Agriculture. PAAT Technical and Scientific Series 2. Foood and Agricultural Organization of the United Nations. Rome. Pp1-52.

Usman, I. S., Bzugu, P. M., Pur, J. T. and Abdullahi, A. (2017). Indigenous Control Methods for Parasites among Pastoralists Communities in Adamawa State, Nigeria Journal of Agricultural Extension, 21 (1): 109-121. http://dx.doi.org/10.4314/jae.v21i1.9

Usman, I. S., Mani, A. U. and Mohammed, I. D. (2015). Indigenous Foot and Mouth Disease Control Methods among Nomadic Cattle Fulani in Adamawa State, Nigeria. Alexandria Journal of Veterinary Science. 45:71-78. 